\title{
The Effect of Servant Leadership on Teacher Performance
}

\author{
Lukman Saepurohman $^{1,2, *}$, Djam'an Satori ${ }^{1}$ \\ ${ }^{1}$ Educational Administration Department, School of Postgraduate Studies, ${ }^{2}$ Headmaster of Elementary School \\ ${ }^{1}$ Universitas Pendidikan Indonesia, ${ }^{2}$ Elementary School Pasirangin 1 \\ ${ }^{1}$ Bandung, ${ }^{2}$ Purwakarta, Indonesia \\ *lukman.sr80@gmail.com
}

\begin{abstract}
One way to increase teacher productivity is to provide adequate facilities by the principal. Teachers led by principals who apply servant leadership styles tend to be more productive because they have more opportunities to develop selfcapacity. Through survey approaches and regression analysis, this study aims to test the influence of servant leadership on teacher performance in elementary schools. Thus, it will be illustrated the extent to which this leadership style contributes to the improvement of teacher performance, as well as being an input material for school stakeholders in improving the implementation of principal leadership.
\end{abstract}

\section{Keywords—servant leadership, teacher performance}

\section{INTRODUCTION}

Schools as educational organizations always increase their productivity so that the quality of education will increase. Increasing the productivity of schools is not only for the organization but also for individuals and groups in schools. Teachers are an important element in the overall effort to increase productivity in schools, given that increasing work productivity can only be done in schools by a teacher [1]. Quality human resources, especially a teacher, is one of the factors that will determine the success of any organization, especially in schools.

From the Badan Human Resources Staffing and Development data for Purwakarta Regency in 2017 \& 2018 there was an increase in the number of civil servant teachers based on functional and structural position classifications, this means that civil servant teachers from 2017 to 2018 experienced an increase in class. After the increase in the class, but the productivity in the presence of the cluster, the teachers are still considered not optimal. The results of the preliminary study regarding the attendance data of the Teacher Working Group (TWG) in Darangdan Subdistrict, especially in Cluster 2 , show that the presence of teachers to participate in these activities is still not optimal. Even though this TWG activity helps teachers to contribute in developing and improving teacher professionalism at work.

The results of the SD Negeri Pasirangin' Education Quality Report card in 2018 showed that the process standard saw a significant decrease in numbers in the last year, even though the previous year the process standard had increased in a better direction. This shows that the learning process carried out by the teacher is still not optimal. Therefore, it is necessary to increase work productivity to improve planning, process and supervision in learning practices in schools. This work productivity cannot be separated from the principal's leadership factor as a leader and also the teacher's motivation factor in providing learning and monitoring learning.

Based on the description above, it shows that the level of work productivity of public elementary school teachers in Purwakarta Regency is assumed to be low and varied. The cause is not just individual factors, but there are a number of factors that shape work productivity. Teacher work productivity is related to the leadership of the principal. The leadership of the principal has an impact on capacity and can develop teacher quality and improve teacher competencies, so that it has a positive impact in the learning process. One of the actions implemented in advancing education in Indonesia is by fostering school principals who are not only competent in one field but competent in another [2]. The leadership of the principal can be supported by servant leadership.

The results of research that have been studied show the success of servant leadership in improving the productive contribution of human resources at SDN Grobogan 1. This shows that the servant leadership leadership implemented in SDN 1 Grobogan, the principal as a leader, places himself as a leader who is always ready to serve, whether asked or not. Various studies on servant leadership have had an influence on human resources, especially productivity, and have been done a lot and it turns out that it can affect school performance even better [3,4].

Indeed, the potential for leadership is in everyone. Everyone has the same opportunity and potential to increase their influence on others. But what type of leader is able to increase his influence on others? Can leadership and good service to others be combined? In fact, it can be done by a great leader in how he serves the organization [5]. 
Servant leadership is demonstrated by empowering and developing people; by expressing humility, authenticity, interpersonal acceptance and service administration; and by providing direction [6]. With the leadership goal to empower and develop people, it will have an impact on work productivity. The leadership of the principal has an impact on capacity and can develop teacher quality and improve teacher competencies, so that it has a positive impact in the learning process [2]. Servant leadership practice is characterized by an increased desire to serve other parties by taking a holistic approach to work, community, and decision-making processes that involve all parties [7]. Joseph [8] said that great leadership is a leader who serves, who can encourage or motivate others to continue working can be articulated.

Research on servant leadership and its impact on teacher performance in primary schools is currently very limited. Previous research has examined the impact of servant leadership on employee engagement [9], organizational performance $[10,11]$, and trust in organizations. In educational organizations, the study of servant leadership in general is more about the impact on the school climate [12], organizational commitments [13], and teacher satisfaction. On this basis, researchers want to further examine and fill the gaps from previous research by focusing on the influence of servant leadership on teacher performance in elementary schools.

\section{METHODS}

Through regression analysis techniques, researchers seek to obtain the magnitude of the influence of servant leadership on teacher performance. The research data was taken from 89 respondents, all of whom were teachers with civil servant status and were already certified, spread across 35 schools. In this study, the method used was quantitative descriptive. As for sampling, researchers used purposive sampling technique in order to obtain a comprehensive data representation.

The servant leadership constructs studied in this study is altruistic calling, emotional healing, wisdom, persuasive mapping, and organizational stewardship [14]. Meanwhile, the teacher performance dimensions is preparation, presentation, execution / methods, personal characteristics, and teacher student interaction [15]. The data was obtained through the dissemination of questionnaires to respondents, then processed with regression techniques to obtain a degree of influence from servant leadership on teacher performance.

\section{RESULTS AND DISCUSSION}

Servant leadership has become one of the many leadership styles that have been studied in the past two decades, especially in educational settings such as schools. The position in which the principal acts as a facilitator, mentor, and serves teachers in the implementation of educator duties becomes a separate concern in the studies that have been carried out. And the results of a number of studies show that servant leadership is relevant to efforts to improve teacher performance. This is also the basis for researchers to conduct the same study, as previously explained, namely to analyze the impact of the implementation of servant leadership by principals on teacher performance in elementary school teachers. Through regression testing using the IBM SPSS 26, the results obtained can be explained in the table below.

TABLE I. REGRESSION TEST

\begin{tabular}{|c|c|c|c|c|c|}
\hline \multirow[t]{2}{*}{ Model } & \multicolumn{2}{|c|}{$\begin{array}{l}\text { Unstandardized } \\
\text { Coefficients }\end{array}$} & \multirow{2}{*}{$\begin{array}{c}\text { Standardized } \\
\text { Coefficients } \\
\text { Beta } \\
\end{array}$} & \multirow[t]{2}{*}{$\mathbf{t}$} & \\
\hline & $B$ & \begin{tabular}{|l} 
Std. Error \\
\end{tabular} & & & \\
\hline (Constant) & 2.148 & 1.218 & & 1.764 & \\
\hline $1 \quad \begin{array}{l}\text { Servant } \\
\text { Leadership }\end{array}$ & .875 & .058 & .852 & 15.173 & \\
\hline
\end{tabular}

The table above shows that servant leadership has a significant positive effect on teacher performance in primary school teachers. With a regression coefficient of 2.148 and 0.875 , it explains that an increase in servant leadership of 0.875 will have a positive impact on increasing teaching performance by 2.148 . Further information displayed in the table above is the result of the $t$ test with a value of 15.173 and sig. 0,000 shows the significant influence of servant leadership on teacher performance so far.

From the results of the above research, it can be explained that teacher performance is influenced by the implementation of servant leadership by the principal. Principals who apply this leadership style effectively can encourage better teacher performance improvement.

Teacher performance must be supported by various factors to achieve goals and targets that will be achieved within a certain period of time, one of which is the application of an effective leadership style [5]. In the current era of school autonomy, improving the quality of education requires a principal's leadership by referring to the serving leader and evaluating teacher performance simultaneously so that it has an impact on improving the quality of teaching.

Leaders have a key role in maintaining the continuity of the organization through efforts to mobilize all personnel according to the responsibilities they carry, especially when faced with progress and change today, the importance of leaders in particular educational organizations or school principals must play an active role in improving the quality of educational services.

Servant leadership is a leadership model that is compatible with educational values, because the spirit underlying servant leadership emphasizes efforts to empower and develop the existence of all members, followers or the people they lead.

The contribution of servant leadership to teacher performance is encourage a moral component, meaning that morals become an integral part of the identity of the leader and are transferred or transmitted to subordinates or followers; (2) focus on service to followers or subordinates, meaning that the leader pays attention to improvement, enhancement and 
achievement of subordinates' personal performance and not just for the benefit of the organization; (3) attention to the success of all stakeholders, meaning that the leader of the organization views that the success of the organization cannot be separated from all internal and external components related to the organization such as: employees, customers, business partners and the community; and (4) self-reflection, as an effort to avoid the proud leader profile. Leaders who carry the servant leadership model provide openness to all members and the organizations they lead to participate actively and creatively and generate great motivation for their employees to work and involve their hearts in the mission and goals of the organization [16].

Principals and teachers in educational institutions are given the authority to make various ways and breakthroughs to improve the quality of schools through the implementation of effective school programs. They are chosen and given the trust to lead schools to be better and build through education to be more advanced. The principal as a leader in the school has a strategic role in efforts to increase the achievement of teacher performance effectiveness, the quality of graduates, who are able to show fighting power and their competitive nature in global competition [17].

The characteristics that inspire servant leadership in its development continue to experience development and development to be applied in the organization by focusing its energy direction on growth and achieving the aspirations of employees. The values of the core elements of servant leadership are based on the value of humility and respect for others with a focus on trust, respect for others and empowerment.

Servant leadership contains ten characters that are described as someone who is willing to listen, empathy, healing, awareness, persuasion, conceptualization, foresight, stewardship, commitment to growth from others, and building community. The leadership function of school principals is not only limited to handling administrative problems and monitoring teacher attendance or making reports to supervisors, more than that, school leaders must be able to have a positive influence that has an impact on teacher performance.

Teacher performance is the most decisive component in the education system as a whole so it must receive central, first and foremost attention. This one figure will always be a strategic spotlight when talking about educational issues, because teachers are always associated with any component in the education system. Teachers play a major role in education development, especially those held formally in schools. Teachers also greatly determine the success of students, especially in relation to the teaching and learning process. The teacher is the component that most influences the achievement of quality education processes and outcomes.

Servant leadership is a type or model of leadership that is developed to overcome the leadership crisis experienced by a society or nation. Servant leaders have a tendency to prioritize the needs, interests and aspirations of the people they lead above themselves. The orientation is to serve, the viewpoint is holistic and operates with spiritual moral standards.

Leaders who prioritize service, starting with the natural feeling of someone who wants to serve and to put service first. Furthermore, consciously, this choice brings aspiration and encouragement in leading others. In addition to influencing how employees behave, managers must certainly master things such as management which is usually needed to overcome complexity by creating rules by compiling formal plans, designing a strict organizational structure, then monitoring the results that have been done by means of compare it with the plan that has been set before. Then the management style in terms of leading and serving in harmony, and there is interaction with the environment. A servant leader is someone who has the strength to serve and lead, the most important thing is to be able to combine the two to strengthen each other positively.

The first and foremost priority of servant leadership is the development of teachers who generate added value for education customers, and then create customer satisfaction followed by continuous success. In non-profit organizations, servant leaders usually tend to try to implement things that are able to make teachers grow commitment. The application of servant leadership is expected to increase work commitment and produce leaders who have serving characteristics so that they can increase teacher performance which has a positive impact on the wider community.

The implementation of servant leadership at the school level is described as having a high sensitivity and concern for the development and self-development of school personnel with managerial and academic abilities and even being able to understand the conditions of teachers, employees and students. The principal also has a personal perspective by positioning school personnel as an important element and needs attention to be empowered, so that this triggers the building of good relationships and spurs the spirit of altruism (selflessness) on the part of the leader [6].

The principal as the leader appears as a servant to meet the needs of personnel who support professional activities at school, in order to achieve quality school services. This can be seen through the establishment and implementation of the leader's strategic policies, such as: managing and mobilizing personnel to spur themselves to improve human resources through open access. The principal applies a pattern of openness and provides opportunities for each school personnel to empower and be empowered to improve the professional abilities of school personnel and achieve school goals together by building familiarity of family relationships.

\section{CONCLUSION}

The results of this study show that teacher performance is significantly influenced by servant leadership. This influence occurs when the principal is able to position himself as a facilitator, mentor and coach for teachers in the development of skills and skills in his duties as a teacher. In addition, through 
the authority, the principal can allocate school resources to meet what the teacher needs, so that teachers become facilitated and can create in the learning process. As for the recommendations given from this study, the principal must have an adequate understanding of the needs and characteristics of each teacher so that the provision of assistance in the form of guidance and mentoring and the provision of learning facilities can be done effectively.

\section{REFERENCES}

[1] S. P. Siagian, Manajemen Sumber Daya Manusia. 2010.

[2] A. S. Sauri, W. Widyasari, and A. Sesrita, "Pengaruh Kepemimpinan Kepala Sekolah Terhadap Kinerja Guru,” Tadbir Muwahhid, vol. 2, no. 1, pp. 73-86, 2018.

[3] N. Nasrun, "Pengaruh Kepemimpinan Kepala Sekolah Terhadap Motivasi Kerja dan Kinerja Guru," Ilmu Pendidik. J. Kaji. Teor. dan Prakt. Kependidikan, 2016.

[4] J. Tatilu, V. P. K. Lengkong, and G. M. Sendow, "Kepemimpinan Transaksional, Transformasional, Servant Leadership Pengaruhnya Terhadap Kinerja Karyawan Pada PT. Sinar Galesong Pratama Manado," J. EMBA J. Ris. Ekon. Manajemen, Bisnis dan Akunt., vol. 2, no. 1, 2014.

[5] R. T. Wilson, "Servant leadership," Int. J. Care Pathways, 1999.

[6] D. van Dierendonck, "Servant leadership: A review and synthesis," Journal of Management. 2011.
[7] Y. Iswanto, "Kepemimpinan Pelayan Era Modern," J. Adm. Kant., vol. 5, no. 2, pp. 157-172, 2017.

[8] E. E. Joseph and B. E. Winston, "A correlation of servant leadership, leader trust, and organizational trust," Leadersh. Organ. Dev. J., 2005.

[9] D. Carter and T. Baghurst, "The Influence of Servant Leadership on Restaurant Employee Engagement," J. Bus. Ethics, 2014.

[10] A. I. Choudhary, S. A. Akhtar, and A. Zaheer, "Impact of Transformational and Servant Leadership on Organizational Performance: A Comparative Analysis," J. Bus. Ethics, 2013.

[11] J. T. McCann, D. Graves, and L. Cox, "Servant Leadership, Employee Satisfaction, and Organizational Performance in Rural Community Hospitals,” Int. J. Bus. Manag., 2014.

[12] G. L. Black, "Correlational Analysis of Servant Leadership and School Climate," J. Cathol. Educ., 2010.

[13] Y. Cerit, "The effects of servant leadership on teachers' organizational commitment in primary schools in Turkey," Int. J. Leadersh. Educ., 2010.

[14] J. E. Barbuto and D. W. Wheeler, "Scale development and construct clarification of servant leadership," Gr. Organ. Manag., 2006.

[15] S. Aimah and B. Purwanto, "Evaluating Teachers' Performance: A Need for Effective Teaching," Celt A J. Cult. English Lang. Teach. Lit., vol. 19, no. 1, pp. 160-173, 2019.

[16] N. Acun-Kapikiran et al., "School effectiveness and school improvement : alternative perspectives," Sch. Eff. Sch. Improv., 2014.

[17] D. L. Parris and J. W. Peachey, "A Systematic Literature Review of Servant Leadership Theory in Organizational Contexts," J. Bus. Ethics, 2013. 